\title{
Processing Factors of Several Pesticides and Degradation Products in Carrots by Household and Industrial Processing
}

\author{
Aurore Bonnechère ${ }^{1}$, Vincent Hanot ${ }^{1}$, Ruben Jolie ${ }^{2}$, Marc Hendrickx ${ }^{2}$, Claude Bragard ${ }^{3}$, Thomas Bedoret ${ }^{4}$ \& \\ Joris Van Loco ${ }^{1}$ \\ ${ }^{1}$ Food, Medicines and Consumer Safety Department, Scientific Institute of Public Health, Ixelles, Belgium \\ ${ }^{2}$ Laboratory of Food Technology, Member of the Leuven Food Science and Nutrition Research Centre \\ (LFoRCe), Heverlee, Belgium \\ ${ }^{3}$ Earth \& Life Institute, Université Catholique de Louvain, Louvain-la-Neuve, Belgium \\ ${ }^{4}$ Redebel sa, Rue de Chassart 4, Saint-Amand, Belgium \\ Correspondence: Vincent Hanot, Food, Medicines and Consumer Safety Department, Scientific Institute of \\ Public Health, Rue Juliette Wytsman 14, BE-1050 Ixelles, Belgium. Tel: 32-2642-5189. E-mail: \\ vincent.hanot@wiv-isp.be
}

Received: March 14, 2012 Accepted: April 11, 2012 Online Published: May 29, 2012

doi:10.5539/jfr.v1n3p68 URL: http://dx.doi.org/10.5539/jfr.v1n3p68

This study was funded by the Belgian Federal Public Service of Health, Food Chain Safety and Environment (contract RT 08/3 PESTRANS)

\begin{abstract}
To quantify the effect of household and industrial processing on the pesticide residues, carrots (Daucus carota) were sprayed during cultivation with three fungicides (boscalid, difenoconazole and tebuconazole), two insecticides (chlorpyrifos and dimethoate) and one herbicide (linuron). The most concentrated formulations were applied pursuant to Good Agricultural Practices, to ensure sufficiently high levels of residues, The subsequent processing conditions were established to correspond as close as possible to the actual conditions that are normally used in industrial practice. The effects of household and industrial processing on the levels of the six pesticide residues and eight associated degradation products were quantified. The washing step allowed decreasing the concentration of residues for all pesticides up to $\sim 90 \%$. It was the most effective step to remove pesticide residues from carrots. The second process, peeling, results in a reduction comparable to washing. The blanching step, combining heat with a large quantity of water, enhanced the elimination of residues (maximum $50 \%$ ). After cutting and washing, the residual concentrations were below $5 \mathrm{ppb}$. However it was observed that the level of pesticide residues was not reduced by microwave cooking. The pesticide residues remaining after previous processing, except difenoconazole, were decreased by sterilization. The cumulative processes allowed the elimination of minimum $90 \%$ of pesticide residues. Degradation products, investigated in this study, were not detected.
\end{abstract}

Keywords: pesticide residues, processing factor, fungicides, Insecticides, herbicides, degradation products

\section{Introduction}

Carrots (Daucus carota) are highly consumed all over the world. With 33.7 million tons of production, carrots represent an important economy for the producing countries (Food and Agriculture organization, 2011). Herbicides are applied on carrot crops to avoid the competition and insecticides and fungicides to avoid pests. This crop is susceptible to bacterial diseases (Xanthomonas campestris pv. carotae and Pectobacterium carotovorum), fungal diseases... (Umesh, Davis, \& Gilbertson, 1998; Farrar, Pryor, \& Davis, 2004; Ministery of Agriculture, 2011). Some pesticides are also applied for conservation of carrots. Effectively, Sclerotinia white mold is a very common disease of many vegetables and carrots are particularly susceptible, especially late in the season and during storage. The disease is present in soil, storage boxes or areas and often shows up after the crop has been harvested (Ministery of Agriculture, 2011).

Food and health authorities around the world are continuously monitoring pesticide residues in fruit and 
vegetables (Rasmusssen, Poulsen, \& Hansen, 2003). The research focuses on the proper use of pesticides in terms of authorization and registration and on compliance with Maximum Residue Limits (MRLs) (Chen et al., 2011; Claeys et al., 2011).

It is important for the consumer to know the intake of pesticide residues. For the most part, pesticide residues in food commodities are reduced or concentrated after several processing such as washing, peeling, blanching, cooking and sterilization (Holland, Hamilton, Ohlin, \& Skidmore, 1994; Kaushik, Satya, \& Naik, 2009; Timme \& Walz-Tylla, 2004). Many researchers have performed studies to determine how much residue can be eliminated by these types of processes (Berrada, Fernandez, Ruiz, Molto, \& Font, 2010; Boulaid, Aguilera, Camacho, Soussi, \& Valverde, 2005; Burchat et al., 1998; Kaushik et al., 2009; Rasmusssen et al., 2003; Lee \& Jung, 2009; Lentza-Rizos \& Balokas, 2001; Sakaliene, Koskinen, Blazauskiene, \& Petroviene, 2009). Timme et al. and Burchat et al. reported results for the peeling and the juicing of carrots. According to them, peeling allows the elimination of residues and the juice is less concentrated in pesticide residues than the pulp (Timme \& Walz-Tylla, 2004; Burchat et al., 1998). In some special cases, more toxic by-products or metabolites can be formed during processing (Holland et al., 1994).

The effect of processing practices on residues has been observed to vary with both crop and pesticides (Burchat et al., 1998). Krol et al. (2000) demonstrated that it is important to use field-sprayed samples, since absorption, translocation and weathering of the pesticide might influence the effect of a process. Indeed the processes acting on pesticide residues in the field (volatilization, hydrolysis...) are relevant for reduction of pesticide residues during processing. The effect of processing can be often (Holland et al., 1994), but not always, correlated with the physico-chemical properties of a pesticide, thus requiring adequate monitoring of processing factors (PF: ratio between a residue concentration in the processed commodity and the raw commodity).

The aim of this study was to obtain such processing factors and to better understand the removal effects of different pesticide residues in processed carrots, by washing, peeling, blanching, microwave cooking, pasteurization and sterilization. The investigations were carried out for six different active substances and seven metabolites (3,5,6-trichloro-2-pyridone and dichloroanilines). Boscalid, chlorpyrifos, difenoconazole, dimethoate-omethoate, linuron and tebuconazole were selected according to MRL exceeding, frequency and level of detection in previous years (AFSCA, 2008; AFSCA, 2007). To analyze the selected pesticides and the degradation products, different analytical methods were used (gas chromatography coupled with a mass spectrometer (GC-MS/MS), ultra performance liquid chromatography coupled with a mass spectrometer (UHPLC-MS/MS)). With obtained concentrations, processing factors have to be calculated to estimate the level of pesticide exposure at the point of consumption after processing (Ling et al., 2011).

\section{Materials and Methods}

\subsection{Materials}

\subsubsection{Pesticides}

Boscalid, linuron and 3,5-dichloroaniline were purchased from Dr. Ehrenstorfer GmbH (Augsburg, Germany) with certified purity of $98.0 \%, 99.0 \%$ and $98.5 \%$ respectively. Chlorpyrifos (99.2\%), 2,3-dichloroaniline (99.9\%), 2,4-dichloroaniline (99.9\%), 2,5-dichloroaniline (99.6\%), 2,6-dichloroaniline (99.4\%), 3,4-dichloroaniline $(99.9 \%)$, dimethoate $(99.4 \%)$, difenoconazole $(97.3 \%)$, omethoate $(98.5 \%)$, tebuconazole $(99.6 \%)$ and 3,5,6-trichloro-2-pyridone (99.3\%) were purchased from Sigma-Aldrich (Seelze, Germany) with certified purity.

\subsubsection{Chemicals for Analysis}

Ultrapure water $(<8 \mathrm{M} \Omega \cdot \mathrm{cm}$ resistance) was supplied by a Millipore purification system (Millipore Milli-Q Water System, Bedford, USA). Methanol and acetonitrile were of HPLC grade from Biosolve (Valkenswaard, The Netherlands). Phosphoric acid (with certified purity of at least 85\%) was obtained from Merck (Darmstadt, Germany). Acetic acid (with certified purity of at least $99 \%$ ) as well as ammonium acetate was purchased from Aldrich (Steinheim, Germany). Ammonium chloride (99.5\%), celite ${ }^{\circledR} 545$, sodium sulphate (99\%) and sodium chloride (99\%) were purchased from VWR (Leuven, Belgium). Acetone Lab-scan with Pestican grade was used and diisopropylether was of "for analysis" grade from Carlo Erba (Rodano, Italy).

The stock solutions of chlorpyrifos, 2,3-dichloroaniline, 2,4-dichloroaniline, 2,5-dichloroaniline, 2,6-dichloroaniline, 3,4-dichloroaniline, 3,5-dichloroaniline and 3,5,6-trichloro-2-pyridone for GC-MS/MS were prepared at $1 \mathrm{mg} \mathrm{mL}^{-1}$ in acetone. Dilute standards at $50 \mu \mathrm{g} \mathrm{mL}^{-1}$ and $5 \mu \mathrm{g} \mathrm{mL}^{-1}$ were prepared by dilution of the stock solution with acetone.

The stock solutions of boscalid, difenoconazole, dimethoate, linuron, omethoate and tebuconazole for LC-MS/MS were prepared at $1 \mathrm{mg} \mathrm{mL}^{-1}$ in acetonitrile containing $0.1 \%$ of acetic acid. Dilute standards at $10 \mu \mathrm{g}$ 
$\mathrm{mL}^{-1}, 1 \mu \mathrm{g} \mathrm{mL} L^{-1}$ and $100 \mathrm{ng} \mathrm{mL}{ }^{-1}$ were prepared by dilution of the stock solution with methanol.

Solutions for calibration were prepared with blank extract of carrots. All solutions were stored at $-18{ }^{\circ} \mathrm{C}$.

\subsection{Produce}

\subsubsection{Cultivation}

The purpose of the field experiment was to produce in parallel two different carrot varieties, Nandrin and Romane, exposed to the six selected pesticides.

Field carrots were grown at Villers-Perwin, Belgium by Redebel sa. Seven applications of pesticides were performed on different crop growth stages as shown in Table 1. High concentrations of the six active substances (see Table 1) were applied following Good Agricultural Practices (GAPs: pre-harvest time, time between two applications...) to ensure sufficiently high pesticide levels. It should be noted that some pesticides are not approved for carrots in Belgium but are in other countries. The formulations were applied using spray boom equipment at the proposed normal settings and timing. From the first spraying until harvest, the total rainfall was $303 \mathrm{~L} \mathrm{~m}^{-2}$ (Figure 1). There was also at least one major rainfall $\left(>5 \mathrm{~L} \mathrm{~m}^{-2}\right)$ between each spraying and between the last spraying and the harvest. By growing the crops in open field, the pesticides were allowed to undergo natural weathering before harvest.

Table 1. Pesticides with their product name, dose of application and the crop stage at the moment of application

\begin{tabular}{|c|c|c|c|c|c|}
\hline Pesticides & $\begin{array}{l}\text { Product } \\
\text { Name }\end{array}$ & $\begin{array}{l}\text { Active } \\
\text { ingredient } \\
\left(\mathrm{g} \mathrm{ha}^{-1}\right)\end{array}$ & $\begin{array}{l}\text { Application } \\
\text { date }\end{array}$ & Crop Stage $\left(\mathrm{BBCH}^{\mathrm{a}}\right)$ & $\begin{array}{l}\text { Number } \\
\text { of days } \\
\text { before } \\
\text { harvest }\end{array}$ \\
\hline \multirow[t]{2}{*}{ Boscalid } & $\begin{array}{l}\text { Signum } \\
\text { WG }\end{array}$ & 267 & $25 / 08 / 2010$ & $\begin{array}{l}\text { BBCH } 48=\text { development of harvestable } \\
\text { vegetative plant parts (DHVP), } 80 \% \text { of } \\
\text { the expected root diameter reached }\end{array}$ & 20 \\
\hline & & 281.2 & $1 / 09 / 2010$ & $\begin{array}{l}\mathrm{BBCH} 48=\mathrm{DHVP}, 80 \% \text { of the expected } \\
\text { root diameter reached }\end{array}$ & 13 \\
\hline Chlorpyrifos & $\begin{array}{l}\text { Dursban } \\
5 \mathrm{G} \mathrm{GR}\end{array}$ & 5000 & $12 / 04 / 2010$ & $\mathrm{BBCH} 00=$ germination, dry seed & \\
\hline \multirow[t]{3}{*}{ Difenoconazole } & $\begin{array}{l}\text { Geyser } 250 \\
\text { EC }\end{array}$ & 260 & $2 / 08 / 2010$ & $\begin{array}{l}\mathrm{BBCH} 45=\mathrm{DHVP}, 50 \% \text { of the expected } \\
\text { root diameter reached }\end{array}$ & 43 \\
\hline & & 250 & $17 / 08 / 2010$ & $\begin{array}{l}\mathrm{BBCH} 47=\mathrm{DHVP}, 70 \% \text { of the expected } \\
\text { root diameter reached }\end{array}$ & 28 \\
\hline & & 263 & $1 / 09 / 2010$ & $\begin{array}{l}\mathrm{BBCH} 48=\mathrm{DHVP}, 80 \% \text { of the expected } \\
\text { root diameter reached }\end{array}$ & 13 \\
\hline \multirow[t]{3}{*}{ Dimethoate } & $\begin{array}{l}\text { Perfekthion } \\
\text { S } 500\end{array}$ & 395 & $9 / 08 / 2010$ & $\begin{array}{l}\mathrm{BBCH} 46=\mathrm{DHVP}, 60 \% \text { of the expected } \\
\text { root diameter reached }\end{array}$ & 36 \\
\hline & & 400 & $17 / 08 / 2010$ & $\begin{array}{l}\mathrm{BBCH} 47=\mathrm{DHVP}, 70 \% \text { of the expected } \\
\text { root diameter reached }\end{array}$ & 28 \\
\hline & & 400 & $25 / 08 / 2010$ & $\begin{array}{l}\mathrm{BBCH} 48=\mathrm{DHVP}, 80 \% \text { of the expected } \\
\text { root diameter reached }\end{array}$ & 20 \\
\hline Linuron & $\begin{array}{l}\text { Linuris } 500 \\
\text { SC }\end{array}$ & 740 & $29 / 06 / 2010$ & $\begin{array}{l}\text { BBCH } 16=\text { leaf development, 6th true } \\
\text { leaf unfolded }\end{array}$ & \\
\hline \multirow[t]{3}{*}{ Tebuconazole } & $\begin{array}{l}\text { Horizon } \\
\text { EW }\end{array}$ & 493 & $9 / 08 / 2010$ & $\begin{array}{l}\mathrm{BBCH} 46=\mathrm{DHVP}, 60 \% \text { of the expected } \\
\text { root diameter reached }\end{array}$ & 36 \\
\hline & & 500 & $25 / 08 / 2010$ & $\begin{array}{l}\mathrm{BBCH} 48=\mathrm{DHVP}, 80 \% \text { of the expected } \\
\text { root diameter reached }\end{array}$ & 20 \\
\hline & & & $14 / 09 / 2010$ & $\begin{array}{l}\text { BBCH } 49=\text { DHVP, expansion complete; } \\
\text { typical form and size of roots reached }\end{array}$ & HARVEST \\
\hline
\end{tabular}

\footnotetext{
${ }^{a}$ The BBCH scale is a system for a uniform coding of phonologically similar growth stages of all mono- and dicotyledonous plant species.
} 


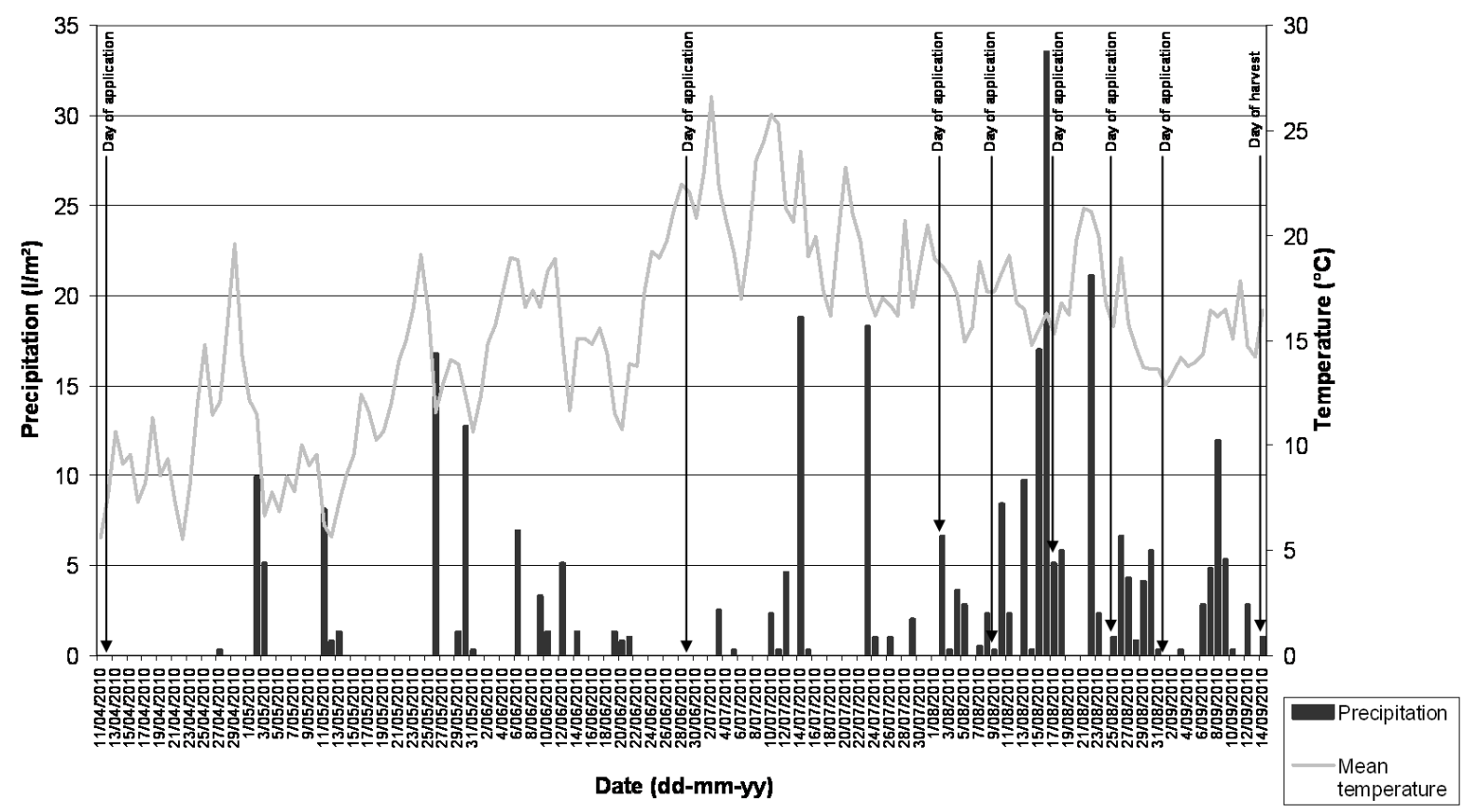

Figure 1. Weather conditions during the period from the first pesticide application to the harvest of two varieties of carrots (Meteorological station of Redebel s.a., Belgium; distance between station and trial: $2.7 \mathrm{~km}$ )

\subsubsection{Harvest}

Plants were dug up with a fork (cleaned with water in advance). Adhering soil was roughly removed without water. Sterile disposable (nitrile) gloves were worn to handle the carrots manually. The end rows $(1.0 \mathrm{~m})$ and the edge rows $(0.5 \mathrm{~m})$ of the plots, as well as diseased and undersized plants, were excluded from sampling. Specimens were randomly collected from the six central rows to obtain more than 240 plants and $45 \mathrm{~kg}$ of carrot weight. A number identified each variety. Carrots were stored in a refrigerator room at $4{ }^{\circ} \mathrm{C}$ from directly after harvest. Vegetables were transported in refrigerated condition to the laboratory on the day of harvest.

\subsection{Sample Preparation and Processing}

\subsubsection{Overview of Processing and Sampling Steps}

Figure 2 shows the sampling flow diagram. To minimize the factor of variability, the two carrot varieties were each divided into two batches of $10 \mathrm{~kg}$ of carrots each, giving four batches in total. The carrot tops were removed; carrots were brushed, washed with water, peeled, cut in small pieces and blanched (Figure 2). Subsequently, the blanched carrot pieces were either pasteurized, sterilized, or microwave-cooked (the latter after frozen storage). All processing steps for a single batch were executed on the same day and processing took place within four days. Meanwhile, the carrots were stored at $4{ }^{\circ} \mathrm{C}$. Processing steps used in these types of studies should correspond as closely as possible to the actual conditions that are normally used in practice.

The standard procedure for sampling and storage of the carrots for pesticide residue analysis, performed after the various processing steps (indicated with * in Figure 2), consisted of (i) homogeneously collecting ca. $500 \mathrm{~g}$ of carrots, (ii) dividing it over five polypropylene bags, (iii) quickly freezing with liquid nitrogen and (iv) storage at $-40^{\circ} \mathrm{C}$. Frozen samples were analyzed for pesticide residues within three months.

\subsubsection{Unprocessed Carrot}

Carrot, which did not undergo any processing, is the "positive control sample", used as reference to calculate the PFs. The harvested carrots without tops were cut into pieces and a representative portion of these pieces $(\sim 10 \mathrm{~kg}$ of carrots taken randomly) was comminuted with a Robot Coupe ${ }^{\circledR}$ R23 (Mont-Ste-Genevieve, Belgium) and frozen until analysis.

\subsubsection{Washing}

After removal of the tops, carrots (about $10 \mathrm{~kg}$ in steps of $2.5 \mathrm{~kg}$ for each batch) were brushed with a hand brush 
to eliminate most of the soil. Subsequently, they were washed by immersion in a bath of fresh tap water $\left(15^{\circ} \mathrm{C}\right.$, $10 \mathrm{~L}$ per $2.5 \mathrm{~kg}$ ) and brushed manually. After $5 \mathrm{~min}$, the carrots were removed from the bath.

\subsubsection{Peeling and Cutting}

After removal of the peels with a manual peeler knife, carrot flesh (about $5 \mathrm{~kg}$ ) was cut in small pieces with a knife. The peels (about $2 \mathrm{~kg}$ ) were homogenized separately.

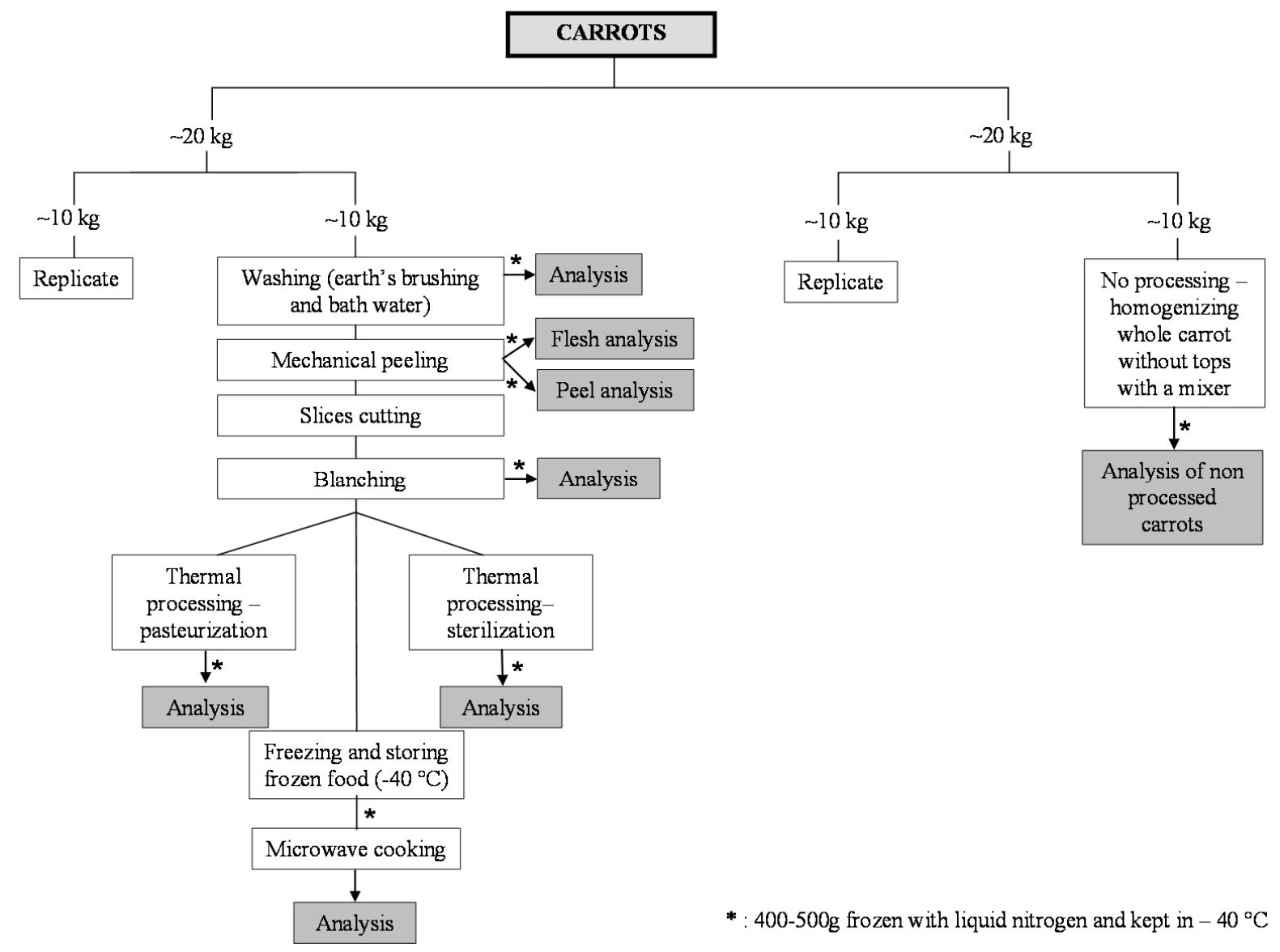

Figure 2. Flow diagram of processing steps and sampling for one variety of carrots

\subsubsection{Blanching}

Approximately $1 \mathrm{~kg}$ of carrots pieces were put in stainless steel baskets and immersed for $4 \mathrm{~min}$ in a $50 \mathrm{~L}$ water bath (Memmert WB 45, Büchenbach, Germany) at $90^{\circ} \mathrm{C}$. Per batch of $6 \mathrm{~kg}$, fresh water was drained away. After the blanching process, the carrots were cooled in tap water $\left(15^{\circ} \mathrm{C}, 15 \mathrm{~L}\right.$ per basket $)$ and dripped. One part of the blanched carrots (ca. $500 \mathrm{~g}$ ) was immediately frozen for pesticide analysis (Section 2.4), while the rest was processed further either by microwave cooking or in-pack pasteurization or in-pack sterilization. The carrots for microwave cooking were stored at $-40{ }^{\circ} \mathrm{C}$ (without liquid nitrogen freezing) for 6 days prior to cooking.

\subsubsection{Microwave Cooking}

Approximately 600-700 g of blanched and frozen carrot pieces was placed in a pyrex recipient and cooked at $800 \mathrm{~W}$ without thawing for $15 \mathrm{~min}$ in a household microwave (Zanker 8500, Zaventem, Belgium).

\subsubsection{In-pack Pasteurization}

Two hundred and ten $( \pm 0.5) \mathrm{g}$ of blanched carrots were weighed in a glass jar $(370 \mathrm{~mL}$ volume, $99 \mathrm{~mm}$ height and $80 \mathrm{~mm}$ diameter) and tap water was added to a total mass of $350.0( \pm 0.5) \mathrm{g}$. For each batch, four jars were prepared and preheated in a water bath at $30{ }^{\circ} \mathrm{C}$. Pasteurization was executed in a pilot-scale water-cascading retort system (Barriquant Steriflow, Paris, France) with a steam-supplied external heat exchanger and cold-water cooling. After an equilibration period in the retort at $40{ }^{\circ} \mathrm{C}(\sim 10 \mathrm{~min})$, the temperature was increased to $90{ }^{\circ} \mathrm{C}$ in $8.5 \mathrm{~min}$ and held for 20 minutes. Thermocouples were placed in the jars for monitoring the temperature and to 
calculate the process value. In accordance with industrial practice, a $\mathrm{P} 90^{\circ} \mathrm{C}$ value of $10.4( \pm 0.3)$ min was obtained (z-value of $10{ }^{\circ} \mathrm{C}$, reference temperature is $90{ }^{\circ} \mathrm{C}$ ). After the pasteurization process, carrots were dripped, sampled and stored.

\subsubsection{In-pack Sterilization}

The same process as described in the previous section was applied except that the temperature was increased to $117^{\circ} \mathrm{C}$ in $8.5 \mathrm{~min}$ and held for $27 \mathrm{~min}$. In accordance with industrial practice, a F0 value of $6.9( \pm 0.3)$ min was obtained (z-value of $10^{\circ} \mathrm{C}$, reference temperature is $121^{\circ} \mathrm{C}$ ).

\subsection{Extraction and Analysis of Pesticides}

\subsubsection{Preliminary Step}

Sampling was performed in a homogenous manner. Aliquot of $500 \mathrm{~g}$ were vacuum-packed in 5 polypropylene bags (ca $100 \mathrm{~g}$ each), frozen with liquid nitrogen and kept at $-40{ }^{\circ} \mathrm{C}$ as standard method of storing samples for pesticide analysis (Figure 2). At this temperature, the plant material was well below its glass transition temperature $\left(\mathrm{T}\right.$ 'g carrots $=-25.5^{\circ} \mathrm{C}$ ) (Slade \& Levine, 1991). Before the extraction step, samples were defrosted and comminuted using a Robot Coupe ${ }^{\circledR}$ R301 Ultra (Mont-Ste-Genevieve, Belgium). All equipment was carefully rinsed with water and detergent between the processing of each sample.

\subsubsection{Analysis by GC-MS/MS}

This method is based on the Mini-Luke method (Luke, Froberg, \& Masumoto, 1975) where the homogeneous sample $(50 \mathrm{~g})$ was extracted with acetone followed by partition with dichloromethane / petroleum ether (1:1). In our method, after an acidification step with phosphoric acid, dichloromethane and petroleum ether was replaced by isopropylether for the liquid-liquid clean up. Eight microliter of the extract containing $0.5 \mathrm{~g}$ matrix per $\mathrm{mL}$ was injected on a gas chromatographic system Varian 3800 coupled with a Varian 320 MS/MS detector. The GC separation was achieved on a VF-5ms column $(30 \mathrm{~m}, 0.25 \mathrm{~mm}$ and $0.25 \mu \mathrm{m})$ from Agilent (Middelburg, The Nederlands) to analyze chlorpyrifos, 2,3-dichloroaniline, 2,4-dichloroaniline, 2,5-dichloroaniline, 2,6-dichloroaniline, 3,4-dichloroaniline, 3,5-dichloroaniline and 3,5,6-trichloro-2-pyridone. The gas flow was set at $1 \mathrm{~mL} \mathrm{~min}{ }^{-1}$. The temperature of oven starting from $75^{\circ} \mathrm{C}$ was maintained during $1.5 \mathrm{~min}$. The increase of $33^{\circ} \mathrm{C} / \mathrm{min}$ to $180^{\circ} \mathrm{C}$ and of $7{ }^{\circ} \mathrm{C} / \mathrm{min}$ to $300^{\circ} \mathrm{C}$. This temperature was maintained during $8.18 \mathrm{~min}$. For the PTV, the temperature was at $85{ }^{\circ} \mathrm{C}$ during $0.3 \mathrm{~min}$ and increased to $300{ }^{\circ} \mathrm{C}$ with $200{ }^{\circ} \mathrm{C} / \mathrm{min}$ and maintained during $4.62 \mathrm{~min}$.

\subsubsection{Analysis by LC-MS/MS}

This method followed the Granby protocol (Granby, Andersen, \& Christensen, 2004) with some adaptations. A sample of $10 \mathrm{~g}$ of carrots was extracted $(5 \mathrm{mM}$ ammonium acetate, $90 \% \mathrm{MeOH}-10 \%$ water) and blended during 1 min with an ultra-turrax homogenizer (Ultra-turrax IKA). The raw extract was diluted with mobile phase A (10\% $\mathrm{MeOH}, 1 \%$ ammonium acetate $0.5 \mathrm{M}$ and $89 \%$ water) to a final concentration equivalent to $0.1 \mathrm{~g}$ matrix per mL and injected. The LC separation was achieved on an Acquity UPLC BEH C18 column $(1.7 \mu \mathrm{m}, 2.1 \times 100 \mathrm{~mm})$ from Waters (Ireland) to analyze boscalid, difenoconazole, dimethoate, linuron, omethoate and tebuconazole. A gradient of mobile phase A and mobile phase B (containing $10 \%$ water, $1 \%$ ammonium acetate $0.5 \mathrm{M}$ and $89 \%$ of methanol) supplied at $0.45 \mathrm{~mL} \mathrm{~min}^{-1}$ was applied. Starting from $99.9 \%$ of mobile phase A, the mobile phase was linearly increased to $99.9 \%$ of mobile phase B in $10 \mathrm{~min}$ and maintained during two min. The gradient was then returned to initial conditions in $0.1 \mathrm{~min}$ and held there for $2.9 \mathrm{~min}$ for stabilization. The mass spectrometer operated in the positive electrospray ionization (ESI) mode and acquired two transitions for each pesticide. The capillary was at $0.6 \mathrm{kV}$, the source temperature at $130{ }^{\circ} \mathrm{C}$, the desolvatation temperature at $400{ }^{\circ} \mathrm{C}$, the cone gas flow at $50 \mathrm{~L} / \mathrm{h}$ and the desolvatation gas flow at $800 \mathrm{~L} / \mathrm{h}$. Argon was used as the collision gas at a setting of 0.35 $\mathrm{mL} \mathrm{min}^{-1}$. The dwell time was $10 \mathrm{~ms}$ per channel for quantifier ions and $5 \mathrm{~ms}$ for qualifier ions.

\subsubsection{Quantification and Quality Control}

Limits of quantifications (LOQs) were based on the signal-to-noise ratio above or equal to 6. LOQs were at $0.010 \mathrm{mg} \mathrm{kg}^{-1}$ for chlorpyrifos, 2,3-dichloroaniline, 2,4-dichloroaniline, 2,5-dichloroaniline, 2,6-dichloroaniline, 3,4-dichloroaniline, 3,5-dichloroaniline and 3,5,6-trichloro-2-pyridone, $0.002 \mathrm{mg} \mathrm{kg}^{-1}$ for boscalid, dimethoate, omethoate and linuron and $0.001 \mathrm{mg} \mathrm{kg}^{-1}$ for difenoconazole and tebuconazole. The linearity of the methods was evaluated in the range of $10-1000 \mu \mathrm{g} \mathrm{kg}^{-1}$ for the pesticide residues analyzed by GC-MS/MS and LC-MS/MS. In all cases, good linearity was achieved with correlation coefficients $>0.995$.

For each batch of analysis, a control (carrots without pesticide residues) and a spiked sample were run. In the control, no pesticide must be found with a concentration superior to the LOQ. The spiked sample must have a 
recovery of extraction between $60 \%$ and $140 \%(\mathrm{SANCO} / 10684 / 2009)$ and the concentrations found in this sample were reported in the control chart. The calibration was checked using a standard injected at the end of the sequence and could not deviate by more than $20 \%$ from the injection of the same standard at the beginning of the sequence.

\subsection{Calculation of Processing Factors}

Processing factors (PFs) were calculated for all transformation steps by a ratio between the pesticide residue concentration $\left(\mathrm{mg} \mathrm{kg}^{-1}\right)$ in the processed commodity and the pesticide residue concentration $\left(\mathrm{mg} \mathrm{kg}^{-1}\right)$ in the raw, non-processed commodity. If a PF is lower than 1, it indicates the reduction of a pesticide, while if higher than 1 , it indicates a concentration in a regulatory practice, regardless of changes in volume or weight for the processed food.

To obtain a PF for each individual processing step, it was necessary to calculate the ratio between the pesticide residue concentration after the process and the pesticide residue concentration before this process. For example, the PF due to peeling was calculating with the concentration of peeled carrots and the concentration of washed carrots.

\section{Results and Discussion}

The study of the degradation and by-products of pesticides during household and industrial transformation of carrots allows calculating the PFs for selected pesticides. These PFs are necessary to refine the risk assessment of frequently detected pesticides.

\subsection{Unprocessed Carrot}

To calculate a PF, it is indispensible to know the pesticide concentration of the raw, unprocessed carrots. All the concentrations of the pesticides measured for the two varieties of carrots are summarized in Table 2 . The degradation products of linuron (2,3-dichloroaniline; 2,4-dichloroaniline; 2,5-dichloroaniline; 2,6-dichloroaniline; 3,5-dichloroaniline and 3,6-dichloroaniline) and of chlorpyrifos (3,5,6-trichloro-2-pyridone) were measured but were not detected.

Table 2. Concentrations ( $\mathrm{mg} \mathrm{kg}^{-1}$ ) of pesticides for the two carrots varieties after various processing steps. Mean values $( \pm \mathrm{SD}, \mathrm{n}=2)$ of two carrots batches are depicted

Variety 1: Nandrin

\begin{tabular}{|c|c|c|c|c|c|c|c|c|}
\hline Pesticides & $\begin{array}{c}\text { LOQ } \\
(\mathrm{mg} / \mathrm{kg})\end{array}$ & $\begin{array}{c}\text { Raw } \\
\text { Mean } \\
\text { values } \\
( \pm \text { SD })\end{array}$ & $\begin{array}{c}\text { Washing } \\
\text { Mean } \\
\text { values } \\
\text { ( } \pm \text { SD) }\end{array}$ & $\begin{array}{c}\text { Peeling } \\
\text { Mean } \\
\text { values } \\
( \pm \text { SD) }\end{array}$ & $\begin{array}{c}\text { Blanching } \\
\text { Mean } \\
\text { values } \\
( \pm \text { SD) }\end{array}$ & $\begin{array}{c}\text { Cooking } \\
\text { Mean } \\
\text { values } \\
( \pm \text { SD })\end{array}$ & $\begin{array}{c}\text { Pasteurization } \\
\text { Mean values } \\
( \pm \text { SD })\end{array}$ & $\begin{array}{c}\text { Sterilization } \\
\text { Mean } \\
\text { values } \\
( \pm \text { SD })\end{array}$ \\
\hline Boscalid & 0.002 & $\begin{array}{c}0.16( \pm \\
0.03)\end{array}$ & $\begin{array}{c}0.036( \pm \\
0.004)\end{array}$ & $\begin{array}{c}0.020( \pm \\
0.003)\end{array}$ & $\begin{array}{c}0.010( \pm \\
0.002)\end{array}$ & $\begin{array}{c}0.012( \pm \\
0.003)\end{array}$ & $\begin{array}{c}0.0085( \pm \\
0.0004)\end{array}$ & $\begin{array}{c}0.010( \pm \\
0.000)\end{array}$ \\
\hline Chlorpyrifos $^{a}$ & 0.010 & $\begin{array}{c}0.089( \pm \\
0.022)\end{array}$ & $\begin{array}{c}0.036( \pm \\
0.005)\end{array}$ & $<$ LOQ & $<$ LOQ & $<$ LOQ & $<$ LOQ & $<$ LOQ \\
\hline Difenoconazole & 0.001 & $\begin{array}{c}0.38( \pm \\
0.01)\end{array}$ & $\begin{array}{c}0.041( \pm \\
0.010)\end{array}$ & $\begin{array}{c}0.011( \pm \\
0.001)\end{array}$ & $\begin{array}{c}0.0090( \pm \\
0.0023)\end{array}$ & $\begin{array}{c}0.011( \pm \\
0.002)\end{array}$ & $\begin{array}{c}0.0084( \pm \\
0.0002)\end{array}$ & $\begin{array}{c}0.011( \pm \\
0.002)\end{array}$ \\
\hline Dimethoate $^{\mathrm{a}}$ & 0.002 & $\begin{array}{c}0.013( \pm \\
0.001)\end{array}$ & $\begin{array}{c}0.0084( \pm \\
0.0013)\end{array}$ & $\begin{array}{c}0.0090( \pm \\
0.0007)\end{array}$ & $\begin{array}{c}0.0037( \pm \\
0.0001)\end{array}$ & $\begin{array}{c}0.0044( \pm \\
0.0002)\end{array}$ & $<$ LOQ & $<$ LOQ \\
\hline Omethoate $^{a}$ & 0.002 & $\begin{array}{c}0.0049( \pm \\
0.0002)\end{array}$ & $\begin{array}{c}0.0043( \pm \\
0.0005)\end{array}$ & $\begin{array}{c}0.0047( \pm \\
0.0004)\end{array}$ & $\begin{array}{c}0.0024( \pm \\
0.0002)\end{array}$ & $\begin{array}{c}0.0025( \pm \\
0.0001)\end{array}$ & $<$ LOQ & $<\mathrm{LOQ}$ \\
\hline Linuron & 0.002 & $\begin{array}{c}0.026( \pm \\
0.003)\end{array}$ & $\begin{array}{c}0.016( \pm \\
0.003)\end{array}$ & $\begin{array}{c}0.015( \pm \\
0.000)\end{array}$ & $\begin{array}{c}0.0099( \pm \\
0.0002)\end{array}$ & $\begin{array}{c}0.0095( \pm \\
0.0006)\end{array}$ & $<\mathrm{LOQ}$ & $<\mathrm{LOQ}$ \\
\hline Tebuconazole & 0.001 & $\begin{array}{c}0.16( \pm \\
0.04)\end{array}$ & $\begin{array}{c}0.050( \pm \\
0.000)\end{array}$ & $\begin{array}{c}0.025( \pm \\
0.002)\end{array}$ & $\begin{array}{c}0.016( \pm \\
0.001)\end{array}$ & $\begin{array}{c}0.0202( \pm \\
0.0001)\end{array}$ & $\begin{array}{c}0.014( \pm \\
0.002)\end{array}$ & $\begin{array}{c}0.017( \pm \\
0.002)\end{array}$ \\
\hline
\end{tabular}


Variety 2: Romane

\begin{tabular}{|c|c|c|c|c|c|c|c|c|}
\hline Pesticides & $\begin{array}{c}\text { LOQ } \\
(\mathrm{mg} / \mathrm{kg})\end{array}$ & $\begin{array}{l}\text { Raw } \\
\text { Mean } \\
\text { values } \\
( \pm \text { SD) }\end{array}$ & $\begin{array}{l}\text { Washing } \\
\text { Mean } \\
\text { values ( } \pm \\
\text { SD) }\end{array}$ & $\begin{array}{l}\text { Peeling } \\
\text { Mean } \\
\text { values } \\
( \pm \text { SD) }\end{array}$ & $\begin{array}{c}\text { Blanching } \\
\text { Mean } \\
\text { values } \\
( \pm \text { SD })\end{array}$ & $\begin{array}{c}\text { Cooking } \\
\text { Mean } \\
\text { values } \\
( \pm \text { SD) }\end{array}$ & $\begin{array}{l}\text { Pasteurization } \\
\text { Mean values } \\
\qquad( \pm \text { SD })\end{array}$ & $\begin{array}{c}\text { Sterilization } \\
\text { Mean } \\
\text { values } \\
( \pm \text { SD })\end{array}$ \\
\hline Boscalid & 0.002 & $\begin{array}{c}0.17( \pm \\
0.01)\end{array}$ & $\begin{array}{c}0.048( \pm \\
0.007)\end{array}$ & $\begin{array}{c}0.018( \pm \\
0.005)\end{array}$ & $\begin{array}{c}0.0094( \pm \\
0.0026)\end{array}$ & $\begin{array}{c}0.012( \pm \\
0.003)\end{array}$ & $\begin{array}{c}0.0096( \pm \\
0.0013)\end{array}$ & $\begin{array}{c}0.010( \pm \\
0.001)\end{array}$ \\
\hline Chlorpyrifos $^{\mathrm{a}}$ & 0.010 & $\begin{array}{c}0.028( \pm \\
0.007)\end{array}$ & $\begin{array}{c}0.014( \pm \\
0.002)\end{array}$ & $<\mathrm{LOQ}$ & $<\mathrm{LOQ}$ & $<\mathrm{LOQ}$ & $<\mathrm{LOQ}$ & $<$ LOQ \\
\hline Difenoconazole & 0.001 & $\begin{array}{c}0.33( \pm \\
0.03)\end{array}$ & $\begin{array}{c}0.047( \pm \\
0.007)\end{array}$ & $\begin{array}{c}0.0063( \pm \\
0.0018)\end{array}$ & $\begin{array}{c}0.0051( \pm \\
0.0004)\end{array}$ & $\begin{array}{c}0.0064( \pm \\
0.0027)\end{array}$ & $\begin{array}{c}0.0046( \pm \\
0.0022)\end{array}$ & $\begin{array}{c}0.0060( \pm \\
0.0029)\end{array}$ \\
\hline Dimethoate $^{\mathrm{a}}$ & 0.002 & $\begin{array}{c}0.0047( \pm \\
0.0003)\end{array}$ & $\begin{array}{c}0.0039( \pm \\
0.0013)\end{array}$ & $\begin{array}{c}0.0045( \pm \\
0.0002)\end{array}$ & $\begin{array}{c}0.0021( \pm \\
0.0002)\end{array}$ & $\begin{array}{c}0.0018( \pm \\
0.0001)\end{array}$ & $<\mathrm{LOQ}$ & $<\mathrm{LOQ}$ \\
\hline Omethoate $^{\mathrm{a}}$ & 0.002 & $\begin{array}{c}0.0028( \pm \\
0.0001)\end{array}$ & $\begin{array}{c}0.0038( \pm \\
0.0002)\end{array}$ & $\begin{array}{c}0.0031( \pm \\
0.0006)\end{array}$ & $\begin{array}{c}0.0021( \pm \\
0.0004)\end{array}$ & $\begin{array}{c}0.0025( \pm \\
0.0000)\end{array}$ & $<\mathrm{LOQ}$ & $<$ LOQ \\
\hline Linuron $^{\mathrm{a}}$ & 0.002 & $\begin{array}{c}0.0042( \pm \\
0.0001)\end{array}$ & $<\mathrm{LOQ}$ & $<\mathrm{LOQ}$ & $<\mathrm{LOQ}$ & $<$ LOQ & $<\mathrm{LOQ}$ & $<$ LOQ \\
\hline Tebuconazole & 0.001 & $\begin{array}{c}0.18( \pm \\
0.01)\end{array}$ & $\begin{array}{c}0.077( \pm \\
0.009)\end{array}$ & $\begin{array}{c}0.033( \pm \\
0.006)\end{array}$ & $\begin{array}{c}0.018( \pm \\
0.0002)\end{array}$ & $\begin{array}{c}0.026( \pm \\
0.000)\end{array}$ & $\begin{array}{c}0.017( \pm \\
0.004)\end{array}$ & $\begin{array}{c}0.020( \pm \\
0.002)\end{array}$ \\
\hline
\end{tabular}

${ }^{\mathrm{a}}$ : These pesticides were detected with concentrations in the raw carrots below $0.1 \mathrm{mg} \mathrm{kg}^{-1}$ or $10 \times$ LOQ.

Three pesticides (chlorpyrifos, dimethoate and linuron) had low residue concentrations despite the high concentrations applied on the crops. Dimethoate and linuron are the two most water soluble pesticides (Table 3). Linuron was applied the 2nd day of application (Figure 1) and 3 days later it rained. With these meteorological conditions, a large amount of linuron was washed off the plantations. As for linuron, dimethoate was applied three times in fully rainy period (3rd, 4th and 5th applications on Figure 1). Since this compound is very water-soluble, it was very likely to be strongly washed off by the rain. For chlorpyrifos, the low concentration can be explained by the early application during the germination stage (Table 1). The concentration in the raw material was rather low and after the peeling, residues were no longer detected. Dimethoate was applied on the crops but omethoate, more toxic than dimethoate, was also measured as the legislation is on the sum of both compounds. For chlorpyrifos, dimethoate, omethoate and linuron, the concentrations were below the minimal concentration $(0.1 \mathrm{mg} / \mathrm{kg}$ or $10 \mathrm{x} \mathrm{LOQ})$ to calculate a PF (OECD, 2008).

The three highest concentrations were obtained for boscalid, difenoconazole and tebuconazole, the three pesticides sprayed during the last two applications before harvest (Table 1 and 4).

Table 3. Physico-chemical properties of pesticides used in this experiment (according to the EU Reference Laboratories for Residues of Pesticides (http://www.crl-pesticides-datapool.eu/default.aspx?ziel=asp/en/stoff.aspx) and on the Pesticide Properties Database of University of Hertfordshire (http://sitem.herts.ac.uk/aeru/footprint/en/))

\begin{tabular}{lllll}
\hline Pesticides & $\begin{array}{l}\text { Water solubility } \\
(\mathbf{m g} / \mathbf{L}) \mathbf{a t} \mathbf{2 0}^{\circ} \mathbf{C}\end{array}$ & $\begin{array}{l}\text { log-octanol-water-partitioning } \\
\text { coefficients }\end{array}$ & $\begin{array}{l}\text { Vapor pressure } \\
\mathbf{( P a )}\end{array}$ & Action mode \\
\hline Boscalid & 4.6 & 2.96 & $7.10^{-7}$ & Non systemic \\
Chlorpyrifos & 1.05 & 4.7 & $1,43.10^{-3}$ & Non systemic \\
Difenoconazole & 15 & 4.2 & $3,3.10^{-8}$ & Systemic \\
Dimethoate & 39800 & 0.704 & $2,5.10^{-4}$ & Systemic \\
Omethoate & 10000 & -0.74 & $3,3.10^{-3}$ & Systemic \\
Linuron & 63.8 & 3 & $5,1.10^{-3}$ & Systemic \\
Tebuconazole & 36 & 3.7 & $1,3.10^{-6}$ & Systemic \\
\hline
\end{tabular}


Table 4. Concentrations $\left(\mathrm{mg} \mathrm{kg}^{-1}\right)$ of pesticides for tops, peels and whole carrots of the two carrots varieties. Mean values $( \pm \mathrm{SD}, \mathrm{n}=2)$ of carrots batches are depicted

\begin{tabular}{|c|c|c|c|c|c|}
\hline Pesticides & $\begin{array}{c}\text { LOQ } \\
(\mathrm{mg} / \mathrm{kg})\end{array}$ & $\begin{array}{c}\text { Tops } \\
\text { Mean values } \\
( \pm \text { SD })\end{array}$ & $\begin{array}{c}\text { Peels } \\
\text { Mean values ( } \pm \\
\text { SD) }\end{array}$ & $\begin{array}{c}\text { Flesh } \\
\text { Mean values } \\
( \pm \text { SD })\end{array}$ & $\begin{array}{c}\text { Whole carrots } \\
\text { Mean values } \\
\text { ( } \pm \text { SD })\end{array}$ \\
\hline Boscalid & 0.002 & $3.73( \pm 0.14)$ & $0.30( \pm 0.03)$ & $0.020( \pm 0.003)$ & $0.16( \pm 0.03)$ \\
\hline Chlorpyrifos & 0.01 & $0.014( \pm 0.001)$ & $<\mathrm{LOQ}$ & $<\mathrm{LOQ}$ & $0.089( \pm 0.022)$ \\
\hline Difenoconazole & 0.001 & $1.70( \pm 0.34)$ & $0.51( \pm 0.10)$ & $0.011( \pm 0.001)$ & $0.38( \pm 0.01)$ \\
\hline Dimethoate & 0.002 & $0.0075( \pm 0.0011)$ & $0.0084( \pm 0.0011)$ & $0.0090( \pm 0.0007)$ & $0.013( \pm 0.001)$ \\
\hline Omethoate & 0.002 & $0.17( \pm 0.02)$ & $0.0048( \pm 0.0000)$ & $0.0047( \pm 0.0004)$ & $0.0049( \pm 0.0002)$ \\
\hline Linuron & 0.002 & $0.0038( \pm 0.0039)$ & $0.027( \pm 0.007)$ & $0.015( \pm 0.001)$ & $0.026( \pm 0.003)$ \\
\hline Tebuconazole & 0.001 & $2.76( \pm 0.09)$ & $0.30( \pm 0.06)$ & $0.025( \pm 0.002)$ & $0.16( \pm 0.04)$ \\
\hline \multicolumn{6}{|c|}{ Variety 2: Romane } \\
\hline Pesticides & $\begin{array}{c}\text { LOQ } \\
(\mathrm{mg} / \mathrm{kg})\end{array}$ & $\begin{array}{c}\text { Tops } \\
\text { Mean values } \\
( \pm \text { SD })\end{array}$ & $\begin{array}{c}\text { Peels } \\
\text { Mean values ( } \pm \\
\text { SD) }\end{array}$ & $\begin{array}{c}\text { Flesh } \\
\text { Mean values } \\
( \pm \text { SD })\end{array}$ & $\begin{array}{c}\text { Whole carrots } \\
\text { Mean values } \\
\text { ( } \pm \text { SD })\end{array}$ \\
\hline Boscalid & 0.002 & $3.45( \pm 0.147)$ & $0.27( \pm 0.059)$ & $0.018( \pm 0.0046)$ & $0.17( \pm 0.011)$ \\
\hline Chlorpyrifos & 0.01 & $\underline{0.010( \pm 0.000)}$ & $0.093( \pm 0.035)$ & $<\mathrm{LOQ}$ & $0.028( \pm 0.0070)$ \\
\hline Difenoconazole & 0.001 & $1.73( \pm 0.115)$ & $0.37( \pm 0.19)$ & $0.0063( \pm 0.0018)$ & $0.33( \pm 0.030)$ \\
\hline Dimethoate & 0.002 & $0.0076( \pm 0.0001)$ & $0.0057( \pm 0.0001)$ & $0.0045( \pm 0.00085)$ & $0.0047( \pm 0.0002)$ \\
\hline Omethoate & 0.002 & $0.065( \pm 0.000)$ & $0.0046( \pm 0.0011)$ & $0.0031( \pm 0.0006)$ & $0.0028( \pm 0.0001)$ \\
\hline Linuron & 0.002 & $<\mathrm{LOQ}$ & $0.0078( \pm 0.0018)$ & $<$ LOQ & $0.0042( \pm 0.0001)$ \\
\hline Tebuconazole & 0.001 & $3.64( \pm 0.0064)$ & $0.36( \pm 0.028)$ & $0.033( \pm 0.0056)$ & $0.18( \pm 0.013)$ \\
\hline
\end{tabular}

By comparing both carrot varieties, the concentrations found show significant differences. Although boscalid and difenoconazole have similar residue concentrations, it is not the case for the chlorpyrifos, dimethoate and linuron. These differences are surprising given that the cultures were pulverized at the same time. However, these pesticides are determined at low concentrations, which increase the level of uncertainty.

Tops and peels were analyzed separately and the concentrations of these parts of carrots are summarized in Table 4. For most pesticides, residues are concentrated in the tops, in agreement with the observations of Burchat et al. (Burchat et al., 1998). Only two pesticides, chlorpyrifos and linuron, were detected in lower concentrations in the tops compared to in the whole raw carrots. Chlorpyrifos was applied during the germination and linuron in an early growth stage when the tops were not very developed (Table 1). Other pesticides were applied later on more developed vegetative plant parts. These results show that the top is the most contaminated part of the carrot. These concentrations in the carrot tops for boscalid, difenoconazole, omethoate and tebuconazole could be a concern as they are used to prepare soups.

\subsection{Washing}

Washing is the most common and straightforward form of processing. It is generally the first step in various types of treatments (household and commercial preparation), which is applied to food raw materials (8). In this study, washing was done with tap water during 5 min with a fixed volume of water. Figure 3 presents all processing factors for the individual processing steps for the six detected pesticides. Results for both carrot varieties are represented separately (bars and the small geometric forms). These results can also be seen in Table 
5, which summarizes all processing factors for the individual processing steps. As explained in the previous section, the residue concentrations of chlorpyrifos, dimethoate, omethoate and linuron were below the minimal concentration to calculate a PF consequently the PFs represented in Table 5 and 8 are indicative for these pesticides.

As shown in Figure 3 and Table 5, up to $89 \%$ of pesticide residues for the carrot variety Nandrin and up to $86 \%$ for the variety Romane could be removed by the washing. These results are in line with previous studies, which have demonstrated that washing could remove up to $89 \%$ of pesticide residues according to the nature of pesticide and the vegetable or fruit (Balinova, Mladenova, \& Shtereva, 2006; Burchat et al., 1998; Chavarri, Herrera, \& Arino, 2005; Fernandez-Cruz et al., 2006; Holland et al., 1994; Kaushik et al., 2009; Lee \& Jung, 2009; Lentza-Rizos \& Balokas, 2001; Ling et al., 2011; Randhawa et al., 2007; Rasmusssen et al., 2003; Timme \& Walz-Tylla, 2004; Zhang, Liu, \& Hong, 2006). Difenoconazole (89\% and 86\%) and tebuconazole (68 and $58 \%$ ) are systemic pesticides but they are more affected by the washing step than boscalid, which is a contact pesticide. Difenoconazole and tebuconazole were applied maximum three times to the culture, which was already at a late stage of the crop stage (at least $50 \%$ of their expected root diameter). Under these conditions, it could be possible that these pesticides do no longer act as systemic.

Table 5. Mean values ( $\pm \mathrm{SD}, \mathrm{n}=2$ ) of processing factors $(\mathrm{PF})$ for individual processing steps for six pesticides in two varieties of carrots. PF above 1 are in bold. Italic characters are used to identify indicative $\mathrm{PFs}^{\mathrm{a}}$

\begin{tabular}{|c|c|c|c|c|c|c|c|c|c|c|c|c|}
\hline \multirow{2}{*}{ Pesticides } & \multicolumn{2}{|c|}{$\begin{array}{c}\text { PF washing } \\
\quad( \pm \mathrm{SD})\end{array}$} & \multicolumn{2}{|c|}{$\begin{array}{l}\text { PF peeling } \\
\qquad( \pm \text { SD) }\end{array}$} & \multicolumn{2}{|c|}{$\begin{array}{l}\text { PF blanching } \\
\qquad( \pm \text { SD) }\end{array}$} & \multicolumn{2}{|c|}{$\begin{array}{c}\text { PF cooking } \\
\quad( \pm \mathrm{SD})\end{array}$} & \multicolumn{2}{|c|}{$\begin{array}{l}\text { PF pasteurization } \\
\qquad( \pm \mathrm{SD})\end{array}$} & \multicolumn{2}{|c|}{$\begin{array}{c}\text { PF sterilization } \\
\qquad( \pm \mathrm{SD})\end{array}$} \\
\hline & Nandrin & Romane & Nandrin & Romane & Nandrin & Romane & $\begin{array}{c}\text { Nandr } \\
\text { in }\end{array}$ & Romane & Nandrin & Romane & Nandrin & Romane \\
\hline Boscalid & $\begin{array}{c}0.22( \pm \\
0.04)\end{array}$ & $\begin{array}{c}0.27( \pm \\
0.04)\end{array}$ & $\begin{array}{c}0.55( \pm \\
0.10)\end{array}$ & $\begin{array}{c}0.37( \pm \\
0.11)\end{array}$ & $\begin{array}{c}0.50( \pm \\
0.07)\end{array}$ & $\begin{array}{c}0.54( \pm \\
0.14)\end{array}$ & $\begin{array}{c}1.23( \pm \\
0.42)\end{array}$ & $\begin{array}{c}1.32( \pm \\
0.36)\end{array}$ & $\begin{array}{c}0.85( \pm \\
0.13)\end{array}$ & $\begin{array}{c}1.03( \pm \\
0.32)\end{array}$ & $\begin{array}{c}1.01( \pm \\
0.15)\end{array}$ & $\begin{array}{c}1.11( \pm \\
0.32)\end{array}$ \\
\hline $\begin{array}{l}\text { Chlorpyrif } \\
\text { os }^{\mathrm{a}}\end{array}$ & $\begin{array}{c}0.40( \pm \\
0.12)\end{array}$ & $\begin{array}{c}0.51( \pm \\
0.15)\end{array}$ & $*$ & $*$ & $*$ & * & * & $*$ & $*$ & $*$ & $*$ & $*$ \\
\hline $\begin{array}{l}\text { Difenocona } \\
\text { zole }\end{array}$ & $\begin{array}{c}0.11( \pm \\
0.03)\end{array}$ & $\begin{array}{c}0.14( \pm \\
0.03)\end{array}$ & $\begin{array}{c}0.27( \pm \\
0.07)\end{array}$ & $\begin{array}{l}0.14( \pm \\
0.058)\end{array}$ & $\begin{array}{c}0.80( \pm \\
0.08)\end{array}$ & $\begin{array}{c}0.81( \pm \\
0.30)\end{array}$ & $\begin{array}{c}1.26( \pm \\
0.34)\end{array}$ & $\begin{array}{c}1.25( \pm \\
0.63)\end{array}$ & $\begin{array}{c}0.93( \pm \\
0.24)\end{array}$ & $\begin{array}{c}0.89( \pm \\
0.44)\end{array}$ & $\begin{array}{c}1.23( \pm \\
0.42)\end{array}$ & $\begin{array}{c}1.17( \pm \\
0.58)\end{array}$ \\
\hline $\begin{array}{l}\text { Dimethoat } \\
e^{e^{e}}\end{array}$ & $\begin{array}{c}0.67( \pm \\
0.11)\end{array}$ & $\begin{array}{c}0.83( \pm \\
0.28)\end{array}$ & $\begin{array}{c}1.08( \pm \\
0.19)\end{array}$ & $\begin{array}{c}1.14( \pm \\
0.38)\end{array}$ & $\begin{array}{c}0.41( \pm \\
0.04)\end{array}$ & $\begin{array}{c}0.46( \pm \\
0.05)\end{array}$ & $\begin{array}{c}1.18( \pm \\
0.07)\end{array}$ & $\begin{array}{c}0.85( \pm \\
0.09)\end{array}$ & $*$ & $*$ & $*$ & $*$ \\
\hline Omethoate & $\begin{array}{c}0.88( \pm \\
0.11)\end{array}$ & $\begin{array}{c}1.36( \pm \\
0.08)\end{array}$ & $\begin{array}{c}1.11( \pm \\
0.16)\end{array}$ & $\begin{array}{c}0.81( \pm \\
0.18)\end{array}$ & $\begin{array}{c}0.51( \pm \\
0.05)\end{array}$ & $\begin{array}{c}0.67( \pm \\
0.18)\end{array}$ & $\begin{array}{c}1.02( \pm \\
0.03)\end{array}$ & $\begin{array}{c}1.22( \pm \\
0.21)\end{array}$ & $*$ & $*$ & $*$ & $*$ \\
\hline Linuron $^{a}$ & $\begin{array}{c}0.63( \pm \\
0.13)\end{array}$ & $*$ & $\begin{array}{c}0.89( \pm \\
0.16)\end{array}$ & $*$ & $\begin{array}{l}0.68( \pm \\
0.018)\end{array}$ & * & $\begin{array}{l}0.96( \pm \\
0.085)\end{array}$ & $*$ & $*$ & $*$ & $*$ & $*$ \\
\hline $\begin{array}{l}\text { Tebuconaz } \\
\text { ole }\end{array}$ & $\begin{array}{c}0.32( \pm \\
0.08)\end{array}$ & $\begin{array}{l}0.42( \pm \\
0.075)\end{array}$ & $\begin{array}{c}0.51( \pm \\
0.04)\end{array}$ & $\begin{array}{c}0.43( \pm \\
0.12)\end{array}$ & $\begin{array}{c}0.65( \pm \\
0.05)\end{array}$ & $\begin{array}{c}0.55( \pm \\
0.10)\end{array}$ & $\begin{array}{c}1.23( \pm \\
0.10)\end{array}$ & $\begin{array}{c}1.40( \pm \\
0.03)\end{array}$ & $\begin{array}{c}0.86( \pm \\
0.14)\end{array}$ & $\begin{array}{c}0.94( \pm \\
0.21)\end{array}$ & $\begin{array}{c}1.06( \pm \\
0.15)\end{array}$ & $\begin{array}{c}1.07( \pm \\
0.11)\end{array}$ \\
\hline
\end{tabular}

${ }^{a}$ : These pesticides were detected with concentrations in the raw carrots below $0.1 \mathrm{mg} \mathrm{kg}^{-1}$ and below $10 \mathrm{x} \mathrm{LOQ}$. That means that the obtained PFs are indicative because there were below the minimum concentration defined by the EU to perform a study to determine PFs [OECD, 2008].

* Not present anymore (<LOQ) after this process, so PF could not be calculated. 


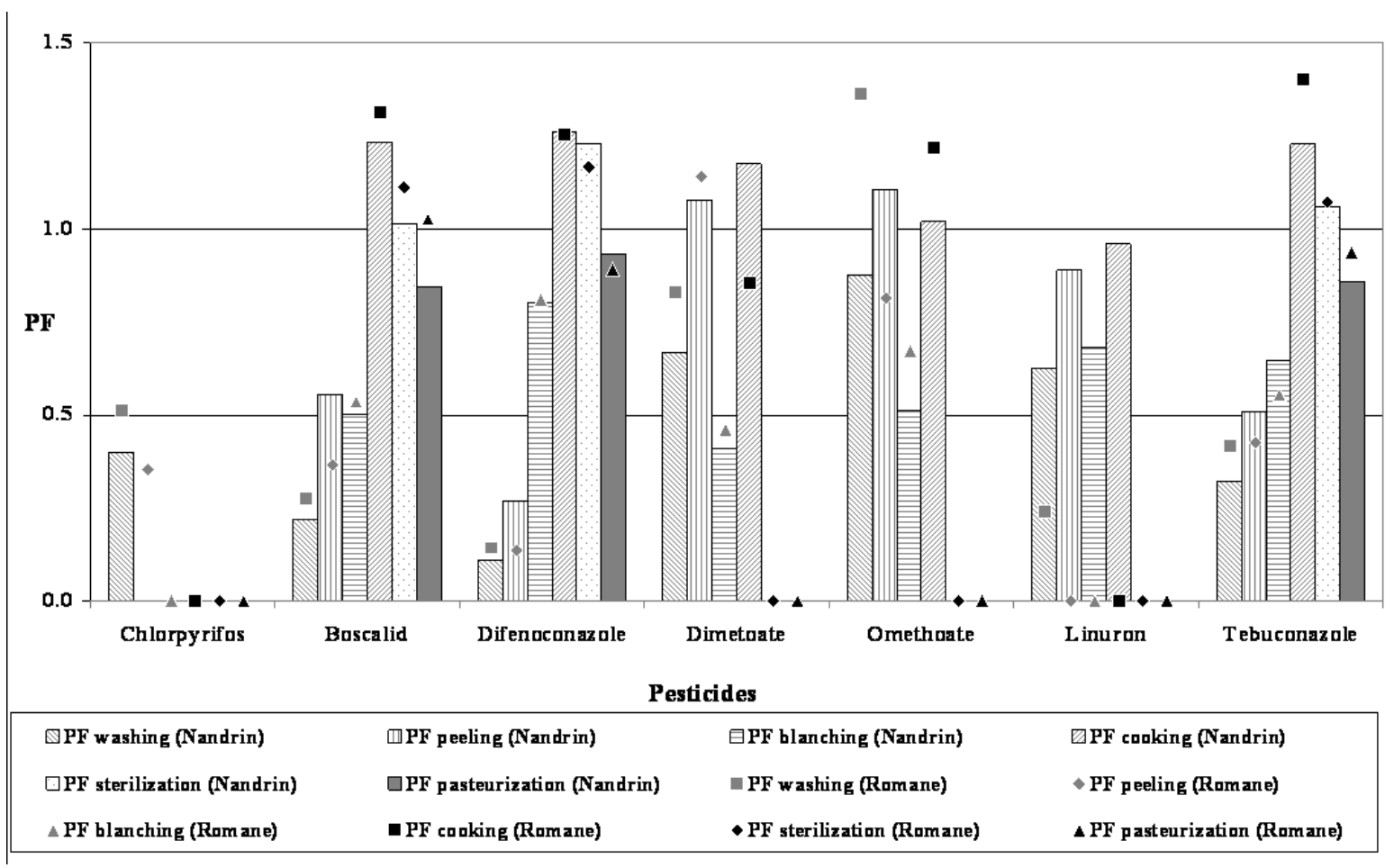

Figure 3. Processing factors for single step for six pesticides in two varieties of carrots. PFs were calculated by the ratio with the pesticide concentration in the processed commodity and the pesticide concentration in the raw commodity. SDs (PF) are resumed in Table 5

In spite of the high standard deviations due to the low concentrations, a reduction by the wash was observed for chlorpyrifos but dimethoate and omethoate were not affected. Dimethoate was also applied late but nevertheless it did not show the same effect as difenoconazole and tebuconazole. Compounds applied to the plants do not have to cross the symplaste to arrive in the xylem contrary to compounds passing by roots. On the other hand, they have to cross the more or less waxy cuticle according to the type of plant and the age. With the age of fractures in the waxy coat form hydrophilic pores allowing the passage of the most hydrophilic molecules as dimethoate (Al-Sayeda, 2007). With this particularity, dimethoate can enter in the vegetable by the flow of xylem and be found in the flesh. As Krol et al. has also confirmed it is possible that pesticide residues are incorporated into plant tissue proportional to the time they remain on biologically active crops in the field. This may even be true of pesticides that are not specifically labelled as systemic (Krol, Arsenault, Harry, \& Incorvia Mattina, 2000) Furthermore Burchat et al. have observed that pesticides residues were significantly reduced following washing of carrots except for the organophosphorus insecticides (Burchat et al., 1998).

\subsection{Peeling}

Peeling is an important step in the processing of most fruits and vegetables. Several methods for peeling in the processing of fruits and vegetables are used such as chemical, mechanical, steam or freeze peeling.

In this study, mechanical peeling using a potato-peeler was carried out. As shown in Table 5 and Figure 3, the elimination of residues further to the peeling was less important than during the wash. For dimethoate and omethoate, there was no decrease of pesticide residues, which is consistent with results of peels and flesh (Table 4). It is also consistent with the results of the wash and the fact that dimethoate is homogeneous distributed in the flesh of the carrot. As observed in Table 4, the concentration in peels can be as high as 46 times that in the flesh.

\subsection{Blanching}

Blanching is a heating process wherein vegetables are immersed into hot water, removed after a short time and finally plunged into cool water to halt the heating process.

As shown in Figure 3 and Table 5, all processing factors for blanching are lower than 1. Almost halve pesticide residue concentrations was lost for both varieties. A substantial decrease was obtained for boscalid with $50 \%$ for "Nandrin" and with $46 \%$ for "Romane". Contrary to the washing step, difenoconazole was the least reduced after the blanching. It is probably due to its log-octanol-water-partitioning coefficient of 4.2 and to its low water 
solubility (Table 3). These physico-chemical properties cause a transfer towards the more lipophilic part of the commodity. Linuron and tebuconazole, which have both a log-octanol-water-partitioning coefficient, also above 3 showed the same trend, namely a lower reduction.

For dimethoate and omethoate, blanching causes an obvious reduction in spite of the high standard deviations for both varieties, which was not the case for other previous processes. These systemic pesticides with high water solubility and low log-octanol-water-partitioning coefficient are well reduced thanks to temperature and the fact that carrots were cut in pieces.

\subsection{Microwave Cooking}

In the current study, microwave cooking was selected. The processes that normally occur with regard to pesticides during cooking are volatilization, hydrolysis and thermal breakdown. Open systems may result in water loss during heating by evaporation, thereby concentrating the pesticide residues if they are not destroyed by heating (Keikotlhaile, Spanoghe, \& Steurbaut, 2010).

After the washing, peeling and blanching steps, the concentrations were very low and the PFs are biased by an important error because of these low concentrations but the tendency could be determined. The microwave cooking does not allow the change of the level of residues present in carrots, except for tebuconazole (Table 5, Figure 3). For this pesticide, the residue concentrations after blanching were well above $10 \mathrm{x} \mathrm{LOQ}$. Consequently, errors were not important and an increase of the tebuconazole level could be seen.

\subsection{Pasteurization}

Pasteurization is a process of heating a food to reduce microorganisms at mild temperature conditions for a definite length of time, and then cooling it immediately. The products obtained by pasteurization (in case of low acid foods) are cool-stable in opposite to the shelf-stability obtained after sterilization. Pasteurization conditions in this study were carefully selected to be as closely in line with commercial practice (i.e., process temperature of $90^{\circ} \mathrm{C}$ and pasteurization value $\mathrm{P} 90^{\circ} \mathrm{C}$ of ca. $10 \mathrm{~min}$ ).

Contrary to blanching, little water was present in the system but a high temperature was used in this process, influencing particularly dimethoate and linuron (Table 5). These pesticides are less reduced by washing and by peeling due their systemic activity. As for blanching, carrots were cut in pieces, the surface of contact with water is more important. These pesticides are highly reduced thanks to their high solubility and the high temperatures imposed by the process of pasteurization (Table 5). Effectively dimethoate-omethoate and linuron were no longer detected.

On one hand, dimethoate, omethoate and linuron, which were little affected by the previous processes, were almost completely eliminated by this process (Table 5, Figure 3 ). On the other hand, there was no decrease in residues observed for difenoconazole, tebuconazole and boscalid (liposoluble and poorly water-soluble) with PFs close to 1 in spite of the high temperature of this process.

\subsection{Sterilization}

The sterilization process is used for a large variety of fruits and vegetables to obtain shelf-stable products.

Sterilization conditions in this study were carefully chosen to follow commercial practice as closely as possible (i.e., process temperature of $117^{\circ} \mathrm{C}$ and process value $\mathrm{F} 0$ of ca. $7 \mathrm{~min}$ ). Observations for sterilization are similar to those obtained for pasteurization. These two processes allow reducing the concentrations for dimethoate and linuron to values lower than the LOQ but no reduction was observed for other pesticides.

\subsection{Overall Processing Factors}

If we take all processes into account, we can compare processing factors for combinations of operations such as washing, peeling, blanching and thermal processing. Figure 4 presents the processing factors for (i) washing and peeling, (ii) washing, peeling and blanching, (iii) washing, peeling, blanching and microwave cooking, (iv) washing, peeling, blanching and sterilization and (v) washing, peeling, blanching and pasteurization for both carrot varieties. Table 6 summarizes all processing factors for the cumulative processes.

For boscalid, chlorpyrifos, difenoconazole and tebuconazole, a strong reduction was mainly observed after the washing and peeling step with more than $80 \%$. On the other hand, for dimethoate, omethoate and linuron, it was the processes of sterilization and pasteurization with their high temperature that allow eliminating them completely (Table 6, Figure 4).

Degradation products were also monitored but there were never found. 
Table 6. Mean values $( \pm \mathrm{SD}, \mathrm{n}=2$ ) of processing factor $(\mathrm{PF})$ for combination of processing for six pesticides in two varieties of carrots. Italic characters are used to identify indicative $\mathrm{PFs}^{\mathrm{a}}$

\begin{tabular}{|c|c|c|c|c|c|c|c|c|c|c|c|c|}
\hline \multirow[t]{2}{*}{ Pesticides } & \multicolumn{2}{|c|}{ PF washing $( \pm$ SD) } & \multicolumn{2}{|c|}{$\begin{array}{c}\text { PF washing and } \\
\text { peeling }( \pm \mathrm{SD})\end{array}$} & \multicolumn{2}{|c|}{$\begin{array}{l}\text { PF washing, peeling } \\
\text { and blanching ( }( \pm \text { SD) }\end{array}$} & \multicolumn{2}{|c|}{$\begin{array}{l}\text { PF washing, peeling, } \\
\text { blanching and } \\
\text { microwaves cooking } \\
\qquad( \pm \text { SD) }\end{array}$} & \multicolumn{2}{|c|}{$\begin{array}{l}\text { PF washing, peeling, } \\
\text { blanching and } \\
\text { pasteurization ( } \pm \\
\text { SD) }\end{array}$} & \multicolumn{2}{|c|}{$\begin{array}{l}\text { PF washing, peeling, } \\
\text { blanching and } \\
\text { sterilization ( } \pm \text { SD) }\end{array}$} \\
\hline & Nandrin & Romane & Nandrin & Romane & Nandrin & Romane & Nandrin & Romane & Nandrin & Romane & Nandrin & Romane \\
\hline Boscalid & $\begin{array}{c}0.12( \pm \\
0.03)\end{array}$ & $\begin{array}{c}0.10( \pm \\
0.03)\end{array}$ & $\begin{array}{c}0.061( \pm \\
0.010)\end{array}$ & $\begin{array}{c}0.054( \pm \\
0.003)\end{array}$ & $\begin{array}{c}0.076( \pm \\
0.028)\end{array}$ & $\begin{array}{c}0.054( \pm \\
0.020)\end{array}$ & $\begin{array}{c}0.062( \pm \\
0.010)\end{array}$ & $\begin{array}{c}0.070( \pm \\
0.005)\end{array}$ & $\begin{array}{c}0.12( \pm \\
0.03)\end{array}$ & $\begin{array}{c}0.10( \pm \\
0.03)\end{array}$ & $\begin{array}{c}0.052( \pm \\
0.009)\end{array}$ & $\begin{array}{c}0.060( \pm \\
0.008)\end{array}$ \\
\hline Chlorpyrifos $^{\mathrm{a}}$ & $\begin{array}{c}0.40( \pm \\
0.16)\end{array}$ & $\begin{array}{c}0.51( \pm \\
021)\end{array}$ & * & * & * & * & $*$ & $*$ & * & * & * & * \\
\hline Difenoconazole & $\begin{array}{c}0.029( \pm \\
0.003)\end{array}$ & $\begin{array}{c}0.019( \pm \\
0.006)\end{array}$ & $\begin{array}{c}0.023( \pm \\
0.001)\end{array}$ & $\begin{array}{c}0.016( \pm \\
0.001)\end{array}$ & $\begin{array}{c}0.029( \pm \\
0.008)\end{array}$ & $\begin{array}{c}0.016( \pm \\
0.011)\end{array}$ & $\begin{array}{c}0.029( \pm \\
0.006)\end{array}$ & $\begin{array}{c}0.020( \pm \\
0.009)\end{array}$ & $\begin{array}{c}0.029( \pm \\
0.003)\end{array}$ & $\begin{array}{c}0.019( \pm \\
0.006)\end{array}$ & $\begin{array}{c}0.022( \pm \\
0.001)\end{array}$ & $\begin{array}{c}0.018( \pm \\
0.007)\end{array}$ \\
\hline Dimethoate $^{\mathrm{e}}$ & $\begin{array}{c}0.67( \pm \\
0.11)\end{array}$ & $\begin{array}{c}0.83( \pm \\
0.28)\end{array}$ & $\begin{array}{c}0.72( \pm \\
0.07)\end{array}$ & $\begin{array}{c}0.95( \pm \\
0.07)\end{array}$ & $\begin{array}{c}0.30( \pm \\
0.02)\end{array}$ & $\begin{array}{c}0.44( \pm \\
0.05)\end{array}$ & $\begin{array}{c}0.035( \pm \\
0.03)\end{array}$ & $\begin{array}{c}0.37( \pm \\
0.03)\end{array}$ & * & * & $*$ & * \\
\hline Omethoate & $\begin{array}{c}0.88( \pm \\
0.11)\end{array}$ & $\begin{array}{c}1.36( \pm \\
0.08)\end{array}$ & $\begin{array}{c}0.97( \pm \\
0.10)\end{array}$ & $\begin{array}{c}0.81( \pm \\
0.23)\end{array}$ & $\begin{array}{c}0.49( \pm \\
0.02)\end{array}$ & $\begin{array}{c}0.75( \pm \\
0.13)\end{array}$ & $\begin{array}{c}0.51( \pm \\
0.03)\end{array}$ & $\begin{array}{c}0.91( \pm \\
0.02)\end{array}$ & * & * & * & * \\
\hline Linuron $^{a}$ & $\begin{array}{c}0.56( \pm \\
0.06)\end{array}$ & * & $\begin{array}{c}0.38( \pm \\
0.04)\end{array}$ & * & $\begin{array}{c}0.36( \pm \\
0.05)\end{array}$ & * & * & * & * & * & * & * \\
\hline Tebuconazole & $\begin{array}{c}0.16( \pm \\
0.04)\end{array}$ & $\begin{array}{c}0.18( \pm \\
0.03)\end{array}$ & $\begin{array}{c}0.11( \pm \\
0.03)\end{array}$ & $\begin{array}{c}0.099( \pm \\
0.007)\end{array}$ & $\begin{array}{c}0.13( \pm \\
0.03)\end{array}$ & $\begin{array}{c}0.099( \pm \\
0.010)\end{array}$ & $\begin{array}{c}0.11( \pm \\
0.03)\end{array}$ & $\begin{array}{c}0.14( \pm \\
0.01)\end{array}$ & $\begin{array}{c}0.16( \pm \\
0.04)\end{array}$ & $\begin{array}{c}0.18( \pm \\
0.03)\end{array}$ & $\begin{array}{c}0.091( \pm \\
0.025)\end{array}$ & $\begin{array}{c}0.11( \pm \\
0.02)\end{array}$ \\
\hline
\end{tabular}

${ }^{\mathrm{a}}$ : These pesticides were detected with concentrations in the raw carrots below $0.1 \mathrm{mg} \mathrm{kg}^{-1}$ or $10 \mathrm{x}$ LOQ. That means that the obtained PFs are indicative because there were below the minimum concentration defined by the EU to perform a study to determine PFs [OECD, 2008].

* Not present anymore (<LOD) after this process, so PF could not be calculated.

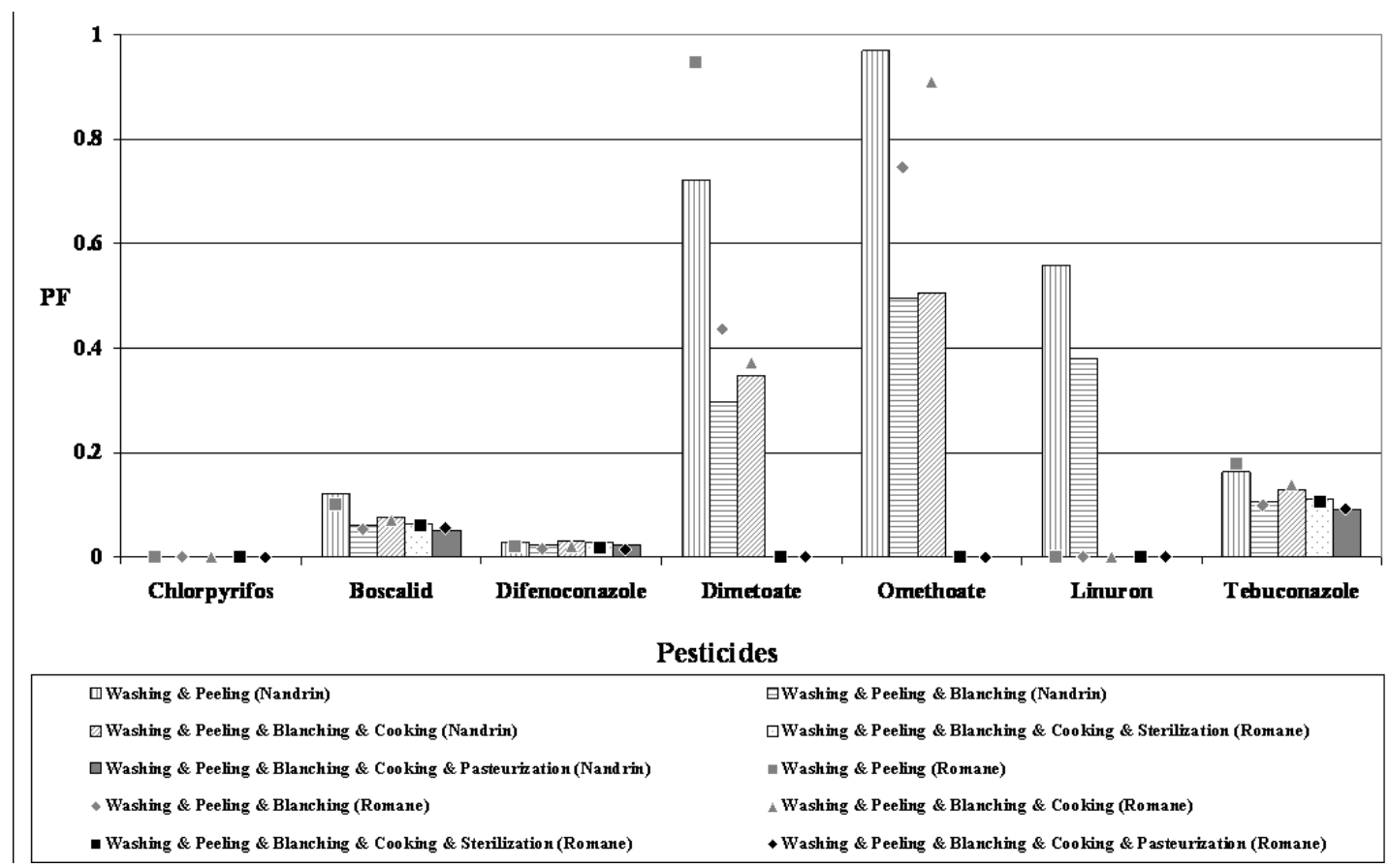

Figure 4. Processing factors for combinations of operations such as washing, peeling, blanching and thermal processing. SDs (PF) are resumed in Table 6 
Pesticide residues were more affected by the washing (generally realized before the launch on the market of carrots) and the peeling, the inevitable process before the consumption of this foodstuff, excepted for dimethoate, omethoate and linuron for which were more reduced by sterilization. On the other hand, the content in residues in carrots remained unchanged in spite of the microwave cooking.

\section{Conclusion}

Various processing factors for washing, peeling, blanching, microwave cooking, sterilization and pasteurization of carrots were determined for boscalid, chlorpyrifos, difenoconazole, dimethoate, omethoate, linuron and tebuconazole. Degradation products of linuron and chlorpyrifos were also monitored but not found.

For chlorpyrifos, dimethoate, omethoate and linuron, the concentrations were very low and the PFs are biased by an important error. Nevertheless, up to $90 \%$ of pesticides in carrots are eliminated after washing and peeling except for dimethoate, omethoate and linuron. Further fifty percent of pesticide residues could be eliminated by blanching step and pesticide residues were not reduced by microwave cooking. Dimethoate, omethoate and linuron were no longer detected after sterilization or pasteurization. On the other hand, boscalid, difenoconazole and tebuconazole seem to be not affected by these two processes in spite of the high temperature used. But at this step, the concentrations were near of $10 \mathrm{ppb}$ and involved important error. With preceding steps, $90 \%$ of residues were eliminated.

Moreover we have showed that two varieties pulverised at the same time with the same solution of active substances, reveal differences in the concentration observed. This variation on the variety on residual concentrations makes the generalization for other combinations pesticides/matrix more difficult.

In this study, most of the processing factors could be explained in terms of water solubility, the log-octanol-water-partitioning coefficients and the systemic properties of the pesticides but also with the agricultural practices (time and number of applications).

In conclusion, various factors have an impact on the fate of pesticide residues after processing and the important steps to reduce pesticide residue in carrots are washing and peeling.

\section{Acknowledgment}

We extend our grateful thanks to Redebel for setting up field trials to obtain commodities, Margot De Haes for her assistance with the processing of the commodities (at KULeuven) and to Martine Deridder for her help during the analysis of the samples.

\section{References}

AFSCA. (2007). Controls of pesticide residues in food Belgium 2006. Retrieved from http://www.favv.be/publicationsthematiques/_documents/2006_Belgium-summary.pdf

AFSCA. (2008). Controls of pesticide residues in food Belgium 2007. Retrieved from http://www.favv.be/publications-en/_documents/2007_Belgium-summary.pdf

Al-Sayeda, H. (2007). Transfert d'un insecticide systémique, l'imidaclopride, chez la tomate: implication duu transport phloémien. Retrieved from http://ethesis.inp-toulouse.fr/archive/00000579/01/al_sayeda.pdf

Balinova, A. M., Mladenova, R. I., \& Shtereva, D. D. (2006). Effects of processing on pesticide residues in peaches intended for baby food. Food Additives and Contaminants, 23, 895-901. http://dx.doi.org/10.1016/j.fct.2009.10.031

Berrada, H., Fernandez, M., Ruiz, M. J., Molto, J. C., \& Font, G. (2010). Surveillance of pesticide residues in fruits from Valencia during twenty months (2004/05). Food Control, 21, 36-44. http://dx.doi.org/10.1016/j.foodcont.2009.03.011

Boulaid, M., Aguilera, A., Camacho, F., Soussi, M., \& Valverde, A. (2005). Effect of household processing and unit-to-unit variability of pyrifenox, pyridaben, and tralomethrin residues in tomatoes. Journal of Agricultural and Food Chemistry, 53, 4054-4058.

Burchat, C. S., Ripley, B. D., Leishman, P. D., Ritcey, G. M., Kakuda, Y., \& Stephenson, G. R. (1998). The distribution of nine pesticides between the juice and pulp of carrots and tomatoes after home processing. Food Additives and Contaminants, 15, 61-71.

Chavarri, M. J., Herrera, A., \& Arino, A. (2005). The decrease in pesticides in fruit and vegetables during commercial processing. International Journal of Food Science \& Technology, 40, 205-211. doi:10.1111/j.1365-2621.2004.00932.x 
Chen, C., Qian, Y., Chen, Q., Tao, C., Li, C., \& Li, Y. (2011). Evaluation of pesticide residues in fruits and vegetables from Xiamen, China. Food Control, 22, 1114-1120. http://dx.doi.org/10.1016/j.foodcont.2011.01.007

Claeys, W. L., Schmit, J. F., Bragard, C., Maghuin-Rogister, G., Pussemier, L., \& Schiffers, B. (2011). Exposure of several Belgian consumer groups to pesticide residues through fresh fruit and vegetable consumption. Food Control, 22, 508-516. http://dx.doi.org/10.1016/j.foodcont.2010.09.037

Farrar, J. J., Pryor, B. M., \& Davis, R. M. (2004). Alternaria diseases of carrot. Plant Disease, 88, 776-784.

Fernandez-Cruz, M. L., Barreda, M., Villarroya, M., Peruga, A., Llanos, S., \& Garcia-Baudin, J. M. (2006). Captan and fenitrothion dissipation in field-treated cauliflowers and effect of household processing. Pest Management Science, 62, 637-645.

Food and Agriculture organization. (2011). FAOSTAT. Retrieved from http://faostat.fao.org/site/567/DesktopDefault.aspx?PageID=567

Granby, K., Andersen, J. H., \& Christensen, H. B. (2004). Analysis of pesticides in fruit, vegetables and cereals using methanolic extraction and detection by liquid chromatography-tandem mass spectrometry. Analytica Chimica Acta, 520, 165-176. http://dx.doi.org/10.1016/j.aca.2004.05.088

Holland, P. T., Hamilton, D., Ohlin, B., \& Skidmore, M. W. (1994). Effects of storage and processing on pesticide residues in plant products. Pure \& Applied Chemistry, 66, 335-356.

Kaushik, G., Satya, S., \& Naik, S. N. (2009). Food processing a tool to pesticide residue dissipation - A review. Food Research International, 42, 26-40. http://dx.doi.org/10.1016/j.foodres.2008.09.009

Keikotlhaile, B. M., Spanoghe, P., \& Steurbaut, W. (2010). Effects of food processing on pesticide residues in fruits and vegetables: A meta-analysis approach. Food and Chemical Toxicology, 48, 1-6. http://dx.doi.org/10.1016/j.fct.2009.10.031

Krol, W. J., Arsenault, T. L., Harry, M., \& Incorvia Mattina, M. J. (2000). Reduction of Pesticide Residues on Produce by Rinsing. Journal of Agricultural and Food Chemistry, 48, 4666-4670.

Lee, M. G.., \& Jung, D. (2009). Processing factors and removal ratios of select pesticides in hot pepper leaves by a successive process of washing, blanching, and drying. Food Science and Biotechnology, 18, 1078-1082.

Lentza-Rizos, C., \& Balokas, A. (2001). Residue levels of chlorpropham in individual tubers and composite samples of postharvest-treated potatoes. Journal of Agricultural and Food Chemistry, 49, 710-714.

Ling, Y., Wang, H., Yong, W., Zhang, F., Sun, L., Yang, M. L., Wu, Y. N. \& Chu, X. G. (2011). The effects of washing and cooking on chlorpyrifos and its toxic metabolites in vegetables. Food Control, 22, 54-58. http://dx.doi.org/10.1016/j.foodcont.2010.06.009

Luke, M. A., Froberg, J. E., \& Masumoto, H. T. (1975). Extraction and cleanup of organochlorine, organophosphate, organonitrogen, and hydrocarbon pesticides in produce for determination by gas-liquid chromatography. Journal of the Association of Official Analytical Chemists, 58, 1020-1026.

Ministery of Agriculture, Food and Rural Affairs (2011). Identification and Management of Carrot Root Diseases. Retrieved from http://www.omafra.gov.on.ca/english/crops/facts/98-001.htm

OECD. (2008). Guideline for testing of chemicals - Magnitude of the pesticide residues in processed commodities. Retrieved from http://www.oecd-ilibrary.org/content/book/9789264067622-en

Randhawa, M. A., Anjum, F. M., Asi, M. R., Butt, M. S., Ahmed, A., \& Randhawa, M. S. (2007). Removal of endosulfan residues from vegetables by household processing. Journal of Scientific \& Industrial Research, 66, 849-852.

Rasmusssen, R. R., Poulsen, M. E., \& Hansen, H. C. (2003). Distribution of multiple pesticide residues in apple segments after home processing. Food Additives and Contaminants, 20, 1044-1063.

Sakaliene, O., Koskinen, W. C., Blazauskiene, G., \& Petroviene, I. (2009). Level and fate of chlorpropham in potatoes during storage and processing. Journal of Environmental Science and Health Part B-Pesticides Food Contaminants and Agricultural Wastes, 44, 1-6. http://ddr.nal.usda.gov/handle/10113/27492

SANCO. (2009). Method validation and quality control procedures for pesticide residues analysis in food and feed. Retrieved from http://ec.europa.eu/food/plant/protection/resources/qualcontrol_en.pdf

Slade, L., \& Levine, H. (1991). Beyond water activity: recent advances based on an alternative approach to the assessment of food quality and safety. Critical Reviews in Food Science and Nutrition, 30, 115-360. 
Timme, G.., \& Walz-Tylla, B. (2004). Effects of food preparation and processing on pesticide residues in commodities of plant origin. In Denis Hamilton \& Stephen Crossley (Ed.), Pesticides residues in food and drinking water: human exposure and risks, pp. 121-148.

Umesh, K. C., Davis, R. M., \& Gilbertson, R. L. (1998). Seed contamination thresholds for development of carrot bacterial blight caused by Xanthomonas campestris pv. carotae. Plant Disease, 82, 1271-1275.

Zhang, Z. Y., Liu, X. J., \& Hong, X. Y. (2006). Effects of home preparation on pesticide residues in cabbage. Food Control, 18, 1484-1487. http://dx.doi.org/10.1016/j.foodcont.2006.11.002 